\title{
Consumer knowledge and attitudes toward healthy eating in Croatia: a cross-sectional study
}

\author{
Marija Ljubičić1,2, Marijana Matek Sarić ${ }^{1}$, Irena Colić Barić3 ${ }^{3}$ Ivana Rumbak ${ }^{3}$, Draženka Komes ${ }^{3}$, \\ Zvonimir Šatalić ${ }^{3}$, and Raquel P. F. Guiné \\ University of Zadar, Department of Health Studies ${ }^{1}$, General Hospital Zadar, Department of Pediatrics ${ }^{2}$, Zadar, \\ University of Zagreb Faculty of Food Technology and Biotechnology ${ }^{3}$ Zagreb, Croatia, CI\&DETS, Polytechnic \\ Institute of Viseu ${ }^{4}$, Viseu, Portugal
}

[Received in January 2017; Similarity Check in January 2017; Accepted in May 2017]

\begin{abstract}
Unlike fast and restaurant food, diet rich in fibre is known to contribute significantly to health. The aim of our study was to assess eating habits such as consumption of fibre-rich, fast, and restaurant food of the general population in Croatia. For this purpose we used a validated survey designed by the Polytechnic Institute Viseu in Portugal, which includes questions about demographics, good eating habits related to the consumption of the main sources of dietary fibre (fruit, vegetables, and whole grains), and unhealthy eating habits related to the consumption of fast food and restaurant meals. Between October 2014 and March 2015 we received answers from 2,536 respondents aged between 18-70 years, of whom $67.4 \%$ were women and $32.6 \%$ were men. Most respondents reported consuming one serving of vegetables and one piece of fruit a day, and whole grains every other day. Women and urban residents reported consuming larger amounts of fruit, vegetables, and whole grains than men $(\mathrm{p}<0.001)$. Men, in turn, reported eating out and eating fast food more often than women $(\mathrm{p}<0.001)$. Eating out highly correlated with eating fast food, which translates to lower consumption of dietary fibre $(\mathrm{p}<0.001)$. Higher education correlated positively with the consumption of fibre-rich food, but it also correlated positively with the consumption of fast and restaurant food $(p<0.001)$. While eating fast food is not the predominant dietary practice in Croatia, over $50 \%$ of respondents have reported eating fast food at least once a week. Our data also indicate that consumption of fruit, vegetables, and whole grains falls below the national and international dietary recommendations.
\end{abstract}

KEY WORDS: dietary fibre; dietary habits; fast food; fruit; restaurant food; vegetables; whole grains

In recent decades, nutritionists have been promoting fibre-rich diet as a way of achieving and maintaining good health. Dietary fibre is not an essential nutrient, but many researchers agree that it reduces the risk of diseases such as cardiovascular disease, digestive and endocrine disorders, diseases of joints and bones, as well as certain malignancies (1-3).

Dietary fibre is made of oligosaccharides, polysaccharides, and hydrophilic derivatives that human digestive enzymes cannot break down into components to be absorbed in the small intestine but that are partly or completely fermented by the microflora of the large intestine (4). It is found in grains, which account for $50 \%$ of total fibre intake in a full meal. Another $30-40 \%$ of fibre comes from vegetables, $16 \%$ from fruit, and the remaining $3 \%$ from other sources. Polysaccharides that make up dietary fibre can be classified as soluble (pectins, beta-glucans, gums, and mucilage) or insoluble (cellullose, hemicellulose, and lignin) (5). Foods rich in soluble fibre are fruit, vegetables, nuts, legumes, and grains such as barley, lentils,

Correspondence to: Marijana Matek Sarić, University of Zadar, Department of Health Studies, Splitska 1, 23000 Zadar, Croatia, e-mail:marsaric@unizd.hr integral rice, and oats. Insoluble dietary fibre is found mainly in bran, whole grains, and fruit peel, and to a lesser extent in fruit, vegetables, and legumes.

For adequate fibre intake the World Health Organization (WHO) recommends the consumption of at least $400 \mathrm{~g}$ of fruit and vegetables a day (6), more specifically $250 \mathrm{~g}$ of fruit (at least 2-3 servings) and $150 \mathrm{~g}$ ( 2 cups or servings) of vegetables $(6,7)$. Dietary guidelines of the US Whole Grains Council (8) recommends at least 3-5 servings of whole grains a day.

Whether someone will consume healthy and fibre-rich food depends on their lifestyle, education, and income. Eating out and eating fast food is associated with lower intake of dietary fibre and body weight gain, even though restaurants have lately been offering more healthy food choices and displaying nutritional information on the menu (9-11).

The aim of our study was to assess the consumption of primary dietary fibre sources (fruit, vegetables, and whole grains) and eating-out habits of the general population in Croatia to see whether and how particular sociodemographic parameters influence food choices. The ultimate goal was to understand the links between Croatian general health and 
diet that need to be addressed in campaigns promoting healthy eating.

\section{MATERIALS AND METHODS}

For this purpose we used a validated survey on eating habits related to dietary fibre, fast food, and eating out created by the Polytechnic Institute in Viseu, Portugal (12). The survey was completed by 2,536 respondents from all over Croatia between October 2014 and March 2015. We recruited through newspaper advertisements, events at shopping centres and town centres, and by word-of-mouth. The intention was to cover the whole range of ages and education levels among the adult urban and rural residents of both genders. The participants were informed about the purpose of the study and assured that participation was voluntary and anonymous. Upon signing consent, the participants filled out the survey in cubicles to ensure their privacy. The study was approved by the Human Research Ethics Committee of the General Hospital Zadar. All data have been collected and analysed in accordance with the Declaration of Helsinki.

\section{Statistical analysis}

The replies were analysed with the SPSS 22.0 software (IBM, Armonk, NY, USA) using descriptive and inferential statistics. Descriptive statistics included frequency distributions, central tendency measures, dispersion measures, and normality. As the Kolmogorov-Smirnov test revealed abnormal distribution we used the median and interquartile range (IR) for descriptive statistics and the non-parametric Mann-Whitney U and Kruskal-Wallis tests for inferential statistics. The associations between variables were explored using Spearman's rank correlation coefficient. The threshold of significance was $\mathrm{p}<0.05$.

\section{RESULTS AND DISCUSSION}

Respondents ranged in age from 18 to 70 years (median=30 IR=24 years). Women prevailed with 1704 $(67.4 \%)$ vs 826 male responders (32.6\%). Fifty-four respondents had primary school education $(2.1 \%), 1,221$ $(48.3 \%)$ high school, and 1,250 (49.5\%) had a university degree. Urban residents made $77.1 \%$ and rural $22.1 \%$ of the respondent population. Nearly half the respondents (1256, 49.6 \%) came from coastal Croatia, which includes Istria, Kvarner, and Dalmatia.

\section{Consumption of fibre-rich food in Croatia}

In view of the WHO (6) and Whole Grain Council recommendations (8), Table 1 shows insufficient consumption of dietary fibre in Croatia. The median of vegetable weekly servings was $7(\mathrm{IR}=4)$, corresponding to an average of one serving a day. The same was true for fruit (median $7, \mathrm{IR}=6)$. Whole grain median was $2(\mathrm{IR}=4)$. These findings are similar to those reported for Portugal (13) and the US (14). In contrast, an earlier research in Croatia (15) reported average daily intake of dietary fibre of $21 \mathrm{~g}$ (recommendations range between 21 and $38 \mathrm{~g}$ a day), and $45 \%$ of the intake referred to cereals. However, the relevance of these findings is limited, as the study included a very small sample. What we find encouraging is that only a handful of our respondents reported never consuming fruit and vegetables This may be related to the fact that nearly a half of our respondents lived in the coastal area with a predominant Mediterranean diet rich in fruit, vegetables, fish, and olive oil.

Influence of sociodemographic factors on consumption of fibre-rich foods

Table 2 shows the influence of sociodemographic factors on the consumption of fibre-rich food. On a weekly basis, women reported to eat more fruit $(p<0.001)$, vegetables $(p=0.023)$, and whole grains $(p<0.001)$ than men. These findings are similar to those of a British study reporting that men consumed less fruit and vegetables than women (16). The authors suggested that such behaviour reflected a lower level of dietary understanding among men, which may also apply for Croatia. Whatever the cause, the significantly lower vegetable consumption by men in our study is in stark contrast to the recommendations issued by the Institute of Medicine of the National Academies that men should eat more fibre than women (17).

This consumption was also higher among urban than rural residents $(p<0.001)$, which may reflect the greater accessibility of fibre-rich food in urban areas (18). This hypothesis should be tested in studies that take into account socioeconomic and demographic factors. Ironically, fibrerich food such as fruit, vegetables, and whole grains are

Table 1 Consumption of fibre-rich food in Croatia

\begin{tabular}{|c|c|c|c|c|c|c|}
\hline \multicolumn{7}{|c|}{ Servings a week, N (\%) } \\
\hline & 0 & $1-7$ & $8-14$ & $15-21$ & $>22$ & Recommended* \\
\hline Fruit & $42(1.6)$ & $1,336(52.8)$ & $719(28.4)$ & $310(12.2)$ & $105(4.1)$ & 14-21 servings or pieces \\
\hline Vegetables & $13(0.5)$ & $1,812(71.6)$ & $577(22.8)$ & $103(4.3)$ & $16(0.6)$ & 14 servings or cups \\
\hline \multicolumn{7}{|c|}{ Servings a week, N (\%) } \\
\hline & 0 & $1-5$ & $6-10$ & $11-15$ & $16-20$ & Recommended** \\
\hline Whole grains & $611(24.1)$ & $1,452(57.5)$ & $423(16.7)$ & $20(0.9)$ & $4(0.2)$ & $21-35$ servings \\
\hline
\end{tabular}

*by the WHO; **by the US Whole Grain Council 
Table 2 Influence of sociodemographic factors on the consumption of fibre-rich food

\begin{tabular}{|c|c|c|c|c|c|c|}
\hline & \multicolumn{2}{|c|}{ Vegetables } & \multicolumn{2}{|c|}{ Fruit } & \multicolumn{2}{|c|}{ Whole cereals } \\
\hline & $\mathbf{N}$ & Mean rank** & $\mathbf{N}$ & Mean rank** & $\mathbf{N}$ & $\begin{array}{c}\text { Mean } \\
\text { rank** }\end{array}$ \\
\hline \multicolumn{7}{|c|}{ Gender (Mann-Whitney U Test) } \\
\hline Women & 1622 & 1283.65 & 1691 & 1297.84 & 1701 & 1329.33 \\
\hline Men & 822 & 1214.18 & 821 & 1171.36 & 822 & 1122.68 \\
\hline $\mathrm{p}^{*}$ & & 0.023 & & 001 & & \\
\hline \multicolumn{7}{|c|}{ Residence (Mann-Whitney U) } \\
\hline Rural & 557 & 1236.11 & 555 & 1178.15 & 558 & 115.42 \\
\hline Urban & 1944 & 1255.27 & 1936 & 1265.45 & 1943 & 1289.94 \\
\hline $\mathrm{p}^{*}$ & & 0.576 & & 11 & & \\
\hline \multicolumn{7}{|c|}{ Education (Kruskal-Wallis Test) } \\
\hline Primary school & 54 & 1072.59 & 54 & 1136.05 & 54 & 1084.56 \\
\hline Secondary school & 1213 & 1174.44 & 1213 & 1197.42 & 1216 & 1197.81 \\
\hline University degree & 1249 & 1348.18 & 1240 & 1314.49 & 1248 & 1327.18 \\
\hline
\end{tabular}

${ }^{*} p<0.05$; **Difference between groups show by mean rank of Mann-Whitney U test for gender and living environment or mean rank of Kruskal-Wallis test for education

Table 3 Eating habits among Croats, stratified by gender, age, residence, and education

\begin{tabular}{|c|c|c|c|c|}
\hline & \multicolumn{2}{|c|}{ Eating out } & \multicolumn{2}{|c|}{ Eating fast food } \\
\hline & $\mathbf{N}$ & Mean rank** & $\mathbf{N}$ & Mean rank** \\
\hline \multicolumn{5}{|c|}{ Gender (Mann-Whitney U Test) } \\
\hline Female & 1696 & 1200.38 & 1691 & 1208.82 \\
\hline Male & 823 & 1382.87 & 821 & 1354.70 \\
\hline $\mathrm{p}^{*}$ & \multicolumn{2}{|c|}{$<0.001$} & \multicolumn{2}{|c|}{$<0.001$} \\
\hline \multicolumn{5}{|c|}{ Residence (Mann-Whitney U) } \\
\hline Rural & 556 & 1205.79 & 554 & 1198.97 \\
\hline Urban & 1941 & 1261.38 & 1936 & 1258.81 \\
\hline $\mathrm{p}^{*}$ & \multicolumn{2}{|c|}{0.103} & \multicolumn{2}{|c|}{0.064} \\
\hline \multicolumn{5}{|c|}{ Education (Kruskal-Wallis Test) } \\
\hline Primary school & 53 & 920.04 & 53 & 1002.80 \\
\hline Secondary school & 1213 & 1194.61 & 1209 & 1208.30 \\
\hline University degree & 1248 & 1332.96 & 1245 & 1309.07 \\
\hline $\mathrm{p}^{*}$ & \multicolumn{2}{|c|}{$<0.001$} & \multicolumn{2}{|c|}{$<0.001$} \\
\hline \multicolumn{5}{|c|}{ Age (Kruskal-Wallis Test) } \\
\hline$<25$ & 1009 & 1591.33 & 1006 & 1530.09 \\
\hline $26-35$ & 487 & 1290.78 & 486 & 1378.94 \\
\hline $36-45$ & 384 & 957.06 & 383 & 1097.36 \\
\hline $46-55$ & 473 & 931.66 & 471 & 852.48 \\
\hline $56-65$ & 142 & 770.24 & 142 & 750.56 \\
\hline$>66$ & 24 & 921.65 & 24 & 771.31 \\
\hline $\mathrm{p}^{*}$ & \multicolumn{2}{|c|}{$<0.001$} & \multicolumn{2}{|c|}{$<0.001$} \\
\hline
\end{tabular}

${ }_{p}^{*}<0.05$; **Difference between groups show by mean rank of Mann-Whitney U test for gender and living environment or mean rank of Kruskal-Wallis test for age and education 
produced in rural areas, yet stores in such areas may not offer these products at affordable prices, and rural residents may not be willing or able to travel long distances to find stores where healthy food is more accessible (19).

Higher education correlated with weekly consumption; respondents holding a university degree consumed the most, followed by respondents with high school and primary school education.

\section{Eating out and eating fast food}

The largest proportion of respondents reported never eating out $(678,26.8 \%)$, followed by those who ate out 5-6 times a week $(452,17.9 \%)$, and those who ate out once a week $(437,17.3 \%)$. A slightly smaller proportion ate out twice a week $(337,13.3 \%)$, and the smallest proportion ate out nearly every day $(138,5.5 \%)$. The median weekly frequency of eating out was $2(\mathrm{IR}=5)$.

Nearly half the respondents $(1,216,48.1 \%)$ reported never consuming fast food, while a little more than a quarter $(701,27.7 \%)$ reported consuming it once a week. A handful of respondents $(22,0.9 \%)$ reported consuming it once a day. The median weekly frequency of eating fast food was $1(\mathrm{IR}=1)$.

Table 3 shows the influence of sociodemographic characteristics on eating out and eating fast food. Men ate out significantly more often than women and also ate fast food significantly more often $(\mathrm{p}<0.001)$. This may reflect women's higher regard of healthy diet, aesthetic concerns, healthier lifestyle, and, presumably, higher proportion of those who can cook.

Urban residents showed a slightly higher tendency toward eating out and fast food than rural residents $(p=0.103$ and 0.064 , respectively), which may reflect greater availability of restaurants and fast food facilities and/or higher income and/or different lifestyle in towns. What we find even more surprising, however, is that these differences between the urban and rural population have almost disappeared.

Paradoxically, higher education correlated with eating out/eating fast food as well as with higher consumption of healthy food $(\mathrm{p}<0.001)$. The first correlation may be owed to a generally higher income and less time to cook and the second to being better informed about healthy food choices.

Respondents below the age of 25 ate out and consumed fast food significantly more often than other age groups. This inclination of younger generations toward fast food is has partly been evidenced by higher consumption of fried potatoes in American adolescents (14). This finding does not come as a surprise; healthy youth is not as concerned with healthy eating as older generations, who start to experience health issues as times goes by. Perhaps a welldesigned future study could provide more answers about unhealthy eating among the young.

\section{Association between the consumption of fibre-rich foods and eating out or eating fast food}

Table 4 shows that respondents who consumed more fruit also consumed more vegetables and whole grains. The strongest association was between fruit and vegetable consumption, for which the determination coefficient was $14.7 \%$. Weaker, yet significant associations were observed between fruit and whole grain consumption $(8.4 \%)$ and between whole grain and vegetable consumption (6.6\%).

An association was also observed between eating out and consuming fast food: the probability that a person eating out would consume fast food was $23.2 \%(p<0.001)$.

Table 4 Associations between the frequencies of consumption of different types of foods

\begin{tabular}{|c|c|c|c|c|c|c|}
\hline & & Salads & Fruit & $\begin{array}{l}\text { Whole } \\
\text { Cereals }\end{array}$ & Eating out & Fast Food \\
\hline \multirow{3}{*}{ Salads } & $\mathrm{r}_{\mathrm{s}}$ & 1.000 & $0.384^{* *}$ & $0.257^{* *}$ & $0.054^{* *}$ & $-0.085^{* *}$ \\
\hline & $\mathrm{p}$ & - & $<0.001$ & $<0.001$ & 0.007 & $<0.001$ \\
\hline & $\mathrm{N}$ & 2521 & 2507 & 2516 & 2512 & 2505 \\
\hline \multirow{3}{*}{ Fruit } & $r_{s}$ & $0.384^{* *}$ & 1.000 & $0.291^{* *}$ & -.030 & $-0.125^{* *}$ \\
\hline & $\mathrm{p}$ & $<0.001$ & - & $<0.001$ & 0.130 & $<0.001$ \\
\hline & $\mathrm{N}$ & 2507 & 2512 & 2507 & 2504 & 2497 \\
\hline \multirow{3}{*}{$\begin{array}{l}\text { Whole } \\
\text { cereals }\end{array}$} & $r_{s}$ & $0.257^{* *}$ & $0.291^{* *}$ & 1.000 & $-0.044^{*}$ & $-0.082^{* *}$ \\
\hline & $\mathrm{p}$ & $<0.001$ & $<0.001$ & - & 0.028 & 0.000 \\
\hline & $\mathrm{N}$ & 2516 & 2507 & 2523 & 2514 & 2508 \\
\hline \multirow{3}{*}{ Eating out } & $\mathrm{r}_{\mathrm{s}}$ & $0.054^{* *}$ & -0.030 & $-0.044^{*}$ & 1.000 & $0.482^{* *}$ \\
\hline & $\mathrm{p}$ & 0.007 & 0.130 & 0.028 & - & $<0.001$ \\
\hline & $\mathrm{N}$ & 2512 & 2504 & 2514 & 2519 & 2510 \\
\hline \multirow{3}{*}{ Fast Food } & $\mathrm{r}_{\mathrm{s}}$ & $-0.085^{* *}$ & $-0.125^{* *}$ & $-0.082^{* *}$ & $0.482^{* *}$ & 1.000 \\
\hline & $\mathrm{p}$ & $<0.001$ & $<0.001$ & $<0.001$ & $<0.001$ & - \\
\hline & $\mathrm{N}$ & 2505 & 2497 & 2508 & 2510 & 2512 \\
\hline
\end{tabular}

${ }^{*}<0.05 ;{ }^{* *} p<0.01 ; r_{s}$ Spearman's rho correlation coefficient 
Respondents who ate out were less likely to consume vegetables or whole grains $(\mathrm{p}<0.001)$. That eating out translates to lower consumption of fibre-rich food, as suggested by Seguin et al. (20), needs to be tested more rigorously, especially since more and more restaurants are offering healthy food choices.

Studies among South Korean adolescents have documented a significant deficit in dietary fibre primarily due to frequent consumption of fast food and unhealthy weight-loss methods. These behaviours have been associated with a higher risk of obesity, hyperlipidaemia, and diabetes and can lead to other chronic diseases (21). Eating out in general and eating fast food in particular have been linked with higher energy intake and intake of poorerquality food. A US study reported higher daily intake of energy, fat, and salt among men than women, which those authors attributed to the greater consumption of fast food (22). We also found that men in our Croatian sample consumed more fast food than women, and we observed an association between eating out and eating fast food. It is more likely that people eating out will eat fast food rather than vegetables and whole-grain meals.

\section{CONCLUSION}

Our findings point to the deficits in the consumption of fruit, vegetables, and whole grains in the Croatian population. These results are not substantially different from those in many parts of the world $(13,14,18,19)$. At the same time, it is encouraging that, similar to the Portuguese population (13), nearly half the Croatian population does not consume fast food, and one quarter does not eat out.

There are several limitations to our study that call for cautious interpretation of the results. The first, shared with other studies, is that the questionnaire does not exclude potato as a vegetable, even though potato is usually grouped with grain or grain products because it contains $12-24 \%$ of starch. If some respondents considered potato a vegetable, our analysis may slightly have overestimated vegetable intake.

Another limitation is that we measured the frequency and not the quantity. We assumed that each consumption corresponded to one serving, but this may be false. Future studies are needed to examine fibre-rich food consumption in more detail.

Limitations aside, our findings suggest the need for campaigns and interventions to encourage the consumption of food containing whole instead of refined grains, which have a significantly lower nutritional value.

Although our study did not rely on food diaries or 24hour dietary recall surveys, it did involve a large crosssection of the Croatian population, allowing a reasonable glimpse into the current trends in the consumption of vegetables, fruit, and whole grains. These findings can help guide the design of public health campaigns and interventions to promote healthier eating.

\section{Acknowledgements}

The authors wish to thank all those involved in the study.

\section{REFERENCES}

1. Threapleton DE, Greenwood DC, Evans CEL, Cleghorn CL, Nykjaer C, Woodhead C, Cade JE, Gale CP, Burley VJ. Dietary fibre intake and risk of cardiovascular disease: systematic review and meta-analysis. Br Med J 2013;347:f6879. doi: 10.1136/bmj.f6879

2. Ben Q, Sun Y, Chai R, Qian A, Xu B, Yuan Y. Dietary fiber intake reduces risk for colorectal adenoma: a meta-analysis. Gastroenterology 2014;146:689-99. doi: 10.1053/j. gastro.2013.11.003

3. Rao SSC, Yu S, Fedewa A. Systematic review: dietary fibre and FODMAP-restricted diet in the management of constipation and irritable bowel syndrome. Aliment Pharmacol Ther 2015;41:1256-70. doi: 10.1111/apt.13167

4. American Association of Cereal Chemists (AAC). The definition of dietary fiber [Report of the Dietary Fiber Definition Committee to the Board of Directors of the AAC]. Cereal Foods World 2001;46:112-126..

5. Brownlee, IA. The physiological roles of dietary fibre. Food Hydrocolloids 2011;25:238-250. doi:10.1016/j. foodhyd.2009.11.013

6. World Health Organization. Measuring intake of fruit and vegetables [displayed 31 May 2017]. Avaliable at http://www. who.int/dietphysicalactivity/publications/f\&v_intake_ measurement.pdf?ua $=1$

7. Verbanac D. O prehrani što, kada i zašto, Školska knjiga, Zagreb, II izdanje, 2003.

8. Whole Grains Council. U.S. Dietary Guidelines and WG [displayed 17 May 2017]. Available at http:// wholegrainscouncil.org/whole-grains-101/us-dietaryguidelines-and-wg

9. Department of Veterans Affairs. Eating out [displayed 17 May 2017]. Avaliable at http://www.publichealth.va.gov/ docs/employeehealth/51-Eating-Out.pdf

10. Bezerra IN, Curioni C, Sichieri R. Association between eating out of home and body weight. Nutr Rev 2012;70:65-79. doi: 10.1111/j.1753-4887.2011.00459.x

11. Lachat C, Nago E, Verstraeten R, Roberfroid D, Van Camp J, Kolsteren P. Eating out of home and its association with dietary intake: a systematic review of the evidence. Obes Rev 2012;13:329-46. doi: 10.1111/j.1467-789X.2011.00953.x

12. Guine RPF, Duarte J, Ferreira M, Correia P, Leal M, Rumbak I, Barić IC, Komes D, Satalić Z, Sarić MM, Tarcea M, Fazakas Z, Jovanoska D, Vanevski D, Vittadini E, Pellegrini N, Szücs V, Harangozó J, El-Kenawy A, El-Shenawy O, Yalçın E, Kösemeci C, Klava D, Straumite E. Knowledge about dietary fibres (KADF): development and validation of an evaluation instrument through structural equation modelling (SEM) Public Health 2016;138:108-18. doi: 10.1016/j.puhe.2016.03.031

13. Martinho CAC, Correia AC, Gonçalves FMJ, Abrantes JL, Carvalho R, Guiné RPF. Study about the knowledge and attitudes of the Portuguese population about food fibres. Curr 
Nutr Food Sci 2013;9:180-8. doi: 10.2174/157340131130903 0002

14. Kimmons J, Gillespie C, Seymour J, Serdula J, Blanck HM. Fruit and vegetable intake among adolescents and adults in the United States: percentage meeting individualized recommendations. Medscape J Med 2009;11:26. PMCID: PMC2654704

15. Pirički AP, Mandić ML, Kenjerić D, Primorac Lj. Food patterns in intake of dietary fibre in small group of Croatian adults. Croat J Food Sci Technol 2009;1:8-14.

16. Baker AH, Wardle J. Sex differences in fruit and vegetable intake in older adults. Appetite 2003;40:269-75. doi: 10.1016/ S0195-6663(03)00014-X

17. Institute of Medicine. Dietary reference intakes for energy, carbohydrate, fiber, fat, fatty acids, cholesterol, protein, and amino acids. Washington, DC: National Academies Press; 2005. doi: $10.17226 / 10490$

18. Kanungsukkasem U, Ng N, Minh HV, Razzaquae A, Ashraf A, Juvekar S, Ahmed SM, Bich TH. Fruit and vegetable consumption in rural adults population in INDEPTH HDSS sites in Asia. Glob Health Action 2009;2(Suppl 1):35-43. doi: 10.3402/gha.v2i0.1988

19. Lutfiyya MN, Chang LF, Lipsky MS. A cross-sectional study of US rural adults' consumption of fruits and vegetables: do they consume at least five servings daily? BMC Public Health 2012;12:280. doi: 10.1186/1471-2458-12-280

20. Seguin RA, Aggarwal A, Vermeylen F, Drewnowski A. Consumption frequency of foods away from home linked with higher body mass index and lower fruit and vegetable intake among adults: a cross-sectional study. J Environ Public Health 2016;2016:3074241. doi: 10.1155/2016/3074241

21. Park S, Na W, Kim M, Kim E, Sohn C. Correlation between intake of dietary fiber and adherence to the Korean National Dietary Guidelines in adolescents from Jeonju. Prev Nutr Food Sci 2012;17:254-60. doi: 10.3746/pnf.2012.17.4.254

22. R An. Fast-food and full-service restaurant consumption and daily energy and nutrient intakes in US adults. Eur J Clin Nutr 2015;70:97-103. doi: 10.1038/ejen.2015.104

\section{Znanja i stavovi potrošača o zdravoj prehrani u Hrvatskoj: presječno ispitivanje}

Poznato je da dijetalna vlakna kao bitna komponenta pravilne prehrane znatno pridonose zdravlju, za razliku od brze hrane i od konzumacije obroka izvan vlastitog doma. Cilj rada bio je procijeniti navike konzumacije ne samo glavnih izvora prehrambenih vlakana voća, povrća i cjelovitih žitarica nego i konzumacije brze hrane i obroka izvan vlastitog doma opće populacije u Republici Hrvatskoj. Korišten je validirani anketni upitnik portugalskog istraživačkog centra Polytechnic Institute Viseu. Upitnik je sadržavao pitanja o demografskim karakteristikama, o dobrim prehrambenim navikama vezanima uz konzumaciju glavnih izvora prehrambenih vlakana i o lošim prehrambenim navikama vezanima uz konzumaciju brze hrane i hrane izvan vlastitog doma. Istraživanje se provodilo od listopada 2014. do ožujka 2015. U istraživanju je sudjelovalo 2536 ispitanika u dobi od 18 do 70 godina, od kojih su 67,4 \% bile žene i 32,6 \% muškarci. Rezultati su pokazali da ispitanici konzumiraju najčešće jedan obrok povrća i jedan komad voća dnevno, a cjelovite žitarice konzumiraju u prosjeku tek svaki drugi dan. Žene i stanovnici urbanog područja konzumiraju veću količinu voća, povrća i cjelovitih žitarica u odnosu na muškarce $(p<0,001)$. Muškarci češće konzumiraju brzu hranu i obroke izvan vlastitog doma u usporedbi sa ženama $(\mathrm{p}<0,001)$. Izgledno je da će osobe koje se hrane izvan doma posegnuti za brzom hranom $(\mathrm{p}<0,001)$, što uzrokuje sniženu konzumaciju namirnica bogatih prehrambenim vlaknima. Postoji pozitivna povezanost više razine obrazovanja i dobrih prehrambenih navika, ali i konzumacije brze hrane i obroka izvan vlastitog doma $(\mathrm{p}<0,001)$. Konzumacija brze hrane u hrvatskoj populaciji nije prevladavajući način prehrane, ali je prisutna u više od $50 \%$ stanovništva. Kad je o hrvatskoj populaciji riječ, unos voća, povrća i cjelovitih žitarica kao glavnih izvora prehrambenih vlakana je ispod preporučenih i nacionalnih i međunarodnih standarda.

KLJUČNE RIJEČI: brza hrana; cjelovite žitarice; dijetalna vlakna; obroci izvan vlastitog doma; povrće; prehrambene navike; voće 